\title{
Reclamation of Saline Water through Solar Desalinization Process under Arid/Semi-Arid of Thar at Umerkot District, Sindh, Pakistan
}

\author{
Muhammad Arshad Ullah', Arshad Ali ${ }^{1}$, Muhammad Aslam¹, Ataullah², Behari Lal ${ }^{2}$ \\ ${ }^{1}$ Land Resources research Institute, National Agricultural Research Centre, Islamabad. Pakistan.45500. \\ ${ }^{2}$ PARC-Arid Zone research Institute, Umerkot, Sindh. Pakistan.
}

*Corresponding Author: Muhammad Arshad Ullah, Land Resources research Institute, National Agricultural Research Centre, Islamabad. Pakistan.45500

\begin{abstract}
Abs tract: Drinking water is essential necessitate for daily life as there is dearth of water in many parts globally. Water quality ought to be such that it can be used by persons for drinking purpose. There are already plenty of solar units present in the market that can do reclamation process, as the available desalinization solar units clean the water safe to drink In desalination process the removal of salt and other minerals from the water is carried out to make it suitable for human consumption and industrial use. Reverse Osmosis (RO) is the one and only one regularly used domestic filtration system that removes even all the impurities. RO is required if the Total Dissolved Solids (TDS) exceeds a certain value. The main objective of this project is to use the sun as source ofenergy through solardesalinization technique which cleans waterfor drinking purpose and installed three orfourdesalinization solar units at village level that operates on solar power. This study showed that 88 liters saline water provided the maximum drinkable water at the adjustment@6 liters/hr/panel at Arid Zone Research Institute, UmerKot. The performance of desalinization solar units installed at Goth Nawab Ji Dhani (Umerkot) using brackish water having $14.45 \mathrm{dSm}^{-1}$ salts removed the toxic salts through solar desalinization technique and reduced it to $0.15 \mathrm{dSm}^{-1}$. Water having so minute salts is fit for drinking purpose. This system creates awareness to the local communities.
\end{abstract}

Keywords: RO (Reverse Osmosis), TDS (Total Dissolved Solids), Desalination solar units

\section{INTRODUCTION}

The total desert land (Tharparkur and Umerkot) is about 05 million hectares out of which 02 million hectares are not cultivable. Agriculture in the desert is entirely dependent on rainfall. The drinkable water is available in patches. Mostly water is brackish in nature. So there is scarcity of good quality of drinkable water in the urban areas as well as remote Thar/desert areas. Solar powered water desalination is increasingly becoming a competitive solution for providing drinking-water in many countries around the world. The desalination of saline water has been documented as one of the most sustainable and fresh water resource substitute. It plays a decisive role in the socio-economic development for many communities and industrial sectors. At present there are over 14,000 desalination plants in function worldwide cleaning several billion gallons of saline water per day. Fifty-seven percent are in the Middle East and Gulf region where large scale conventional heat and power plants are installed. However, since they are operated using fossil fuels, they are becoming expensive to operate and the pollution and greenhouse gas emissions they produce are increasingly recognized as harmful to the environment. Moreover, such plants are not economically viable in remote areas, even in coastal regions where seawater is abundant. Many areas often experience a shortage of fossil fuels and inadequate and unreliable electricity supply. The integration of renewable energy resources in desalination and water purification is becoming more viable as costs of conventional systems increase, commitments to reduce greenhouse gas emissions are implemented and targets for exploiting renewable energy are set. Thus, solar energy could provide a sustainable alternative to drive the desalination plants, especially in countries which lie on the solar belt such as Africa, the Middle East, India, Pakistan and China. Pure water is the basic necessary for all living organism. Now days, the availability of clean water resource is a major issue for mankind. A lack of infrastructure for water storage and distribution is also a factor in the developing world. More than $71 \%$ of the earth surface is covered with the water, but only $1 \%$ 
clean drinkable water is available with the international standards (Dev Rahul and Tiwari, 2009).Provision of safe drinking water is a vital for the life and domino effect in socio-economic development. Fresh water resources are rapidly declining due to increase of the population and mismanagement and the emerging climate changes are further accelerating the proce ss of water scarcity. This is a need of the time to use saline water drinkable particularly in the coastal areas which have lowest access to the safe drinking water and ground water is often brackish. The coastal population is prone to a number of health problems because of using perilous water. Distillation is one of many processes that can be used for water purification. This requires an energy input, as heat, solar radiation can be the source of energy. In this process, water is evaporated, thus separating water vapor from dissolved matter, which is condensed as pure water. Unadventurous technologies used for disinfection of unpotable water include ozonation, chlorination, and artificial UV radiation. These technologies are capital intensive, require sophisticated equipment, and demand skilled operators (Acher et al., 1997; Pelizzetti, 1999; U.S. Environmental Protection Agency, 1996).Unhygienic water causes an anticipated 6 to 60 billion cases of gastrointestinal illness annually. Nearly all of these cases occur in rural areas of developing nations where the water supply is polluted with a range of microorganisms, counting viruses, fecal coliforms, and protozoa, and adequate sanitation is unavailable. The need for a low-cost, lowmaintenance, and effective disinfection system for the improvement of water quality is high. Boiling, for example, needs about $1 \mathrm{~kg}$ of wood/liter of water, and abuse of sodium hypochlorite solution poses a safety hazard (Acra et al., 1990; Bunce, 1991; Ishikawa et al., 1986).

\section{Experiment Proceidure/ Design}

The following are the description of solar powered water desalination system AROCELL solar water purifies Australian technology. It only use sun energy, there are no moving parts, no electronics. It is robust and easy to setup, low maintenance and very low in operating cost because the water purifier only need solar energy. The feed water is supplied by gravity or pressure pump CAROCELL direct solar powered desalination technology, working at ambient temperature, heats the input water causing vapors condensation change precluding all bacteria and pathogens, therefore eliminating all water borne diseases Exposure to ultra violet light and extreme heat from solar energy through the advanced composite panels enhances the germ killing process. CAROCELL's increased efficiency $(65 \%$ with peak efficiencies above $80 \%)$ over other solar distillation products $(30-40 \%)$ is a combination of the proprietary materials used to dramatically increase the temperature of the feed water on the solar collector which enhances the evaporation / condensation processes inside the panel. Additionally, this sophisticated geometrical design has easy maintenance, optimum performance and a self-controlling natural convection loop enabling widely superior energy recovery.

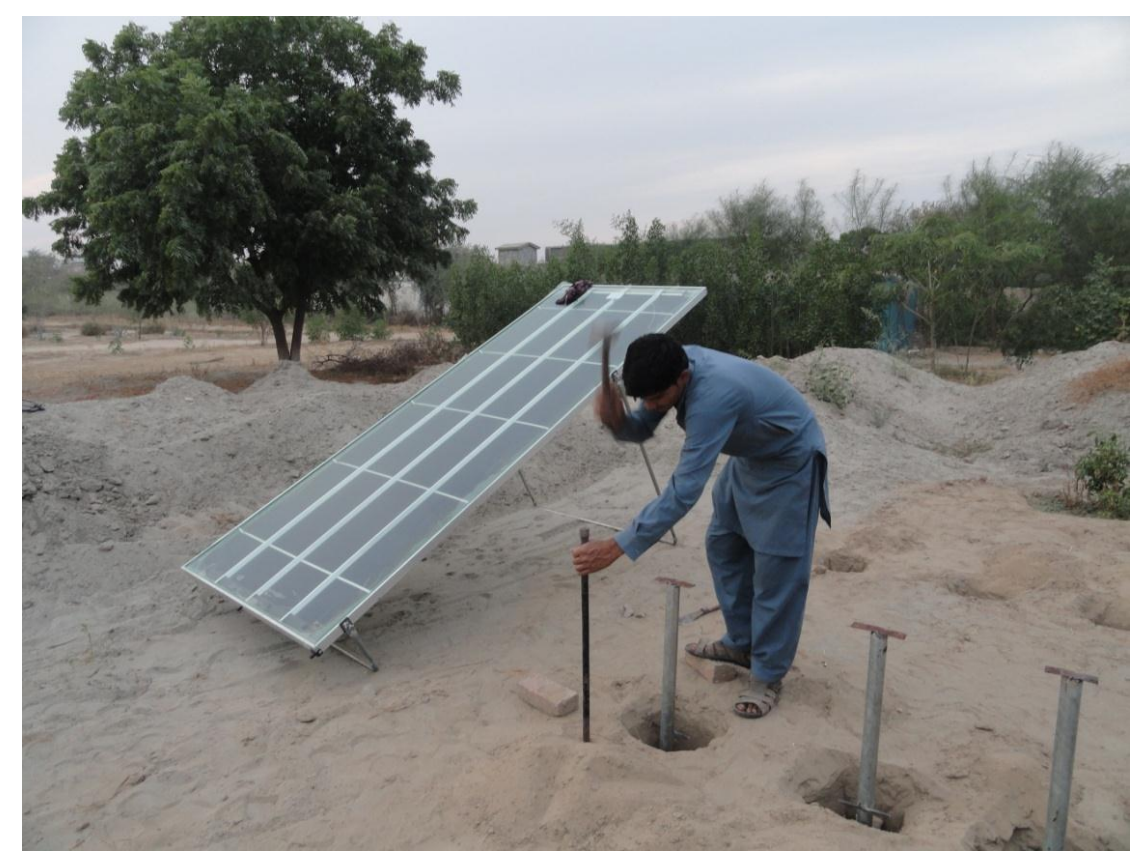

Alignment of poles for solar desalination mounted on pole 


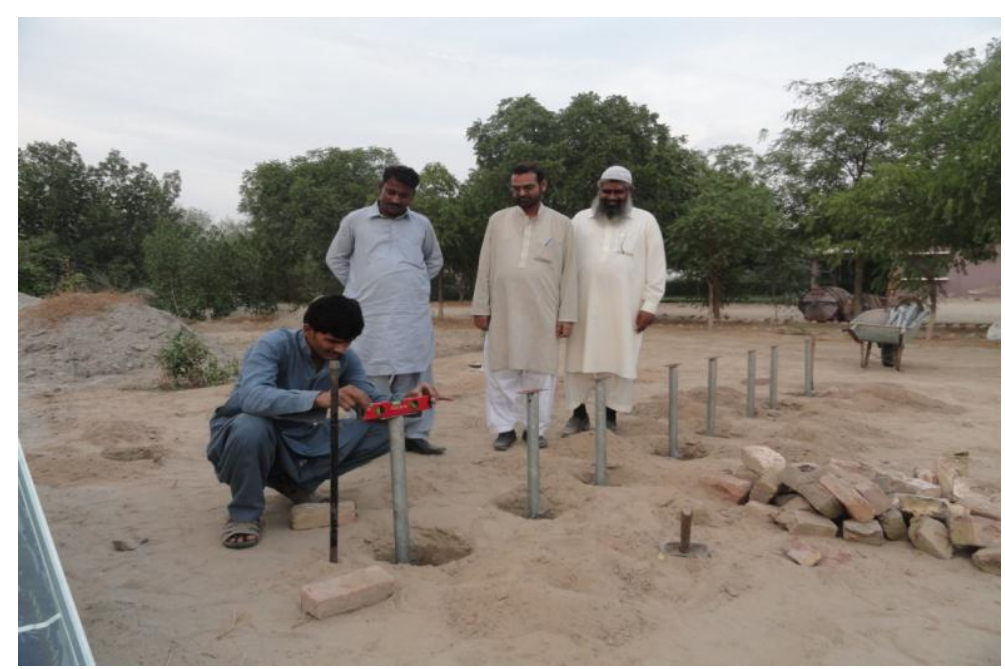

Zero level of poles installation for desalination mounted on pole

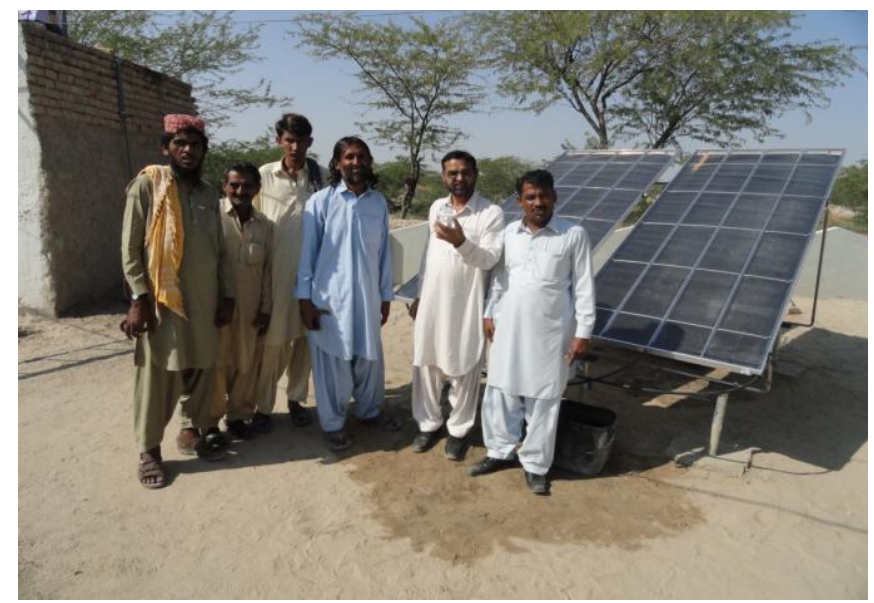

Train the farmers for operation and maintenance of solar desalination system

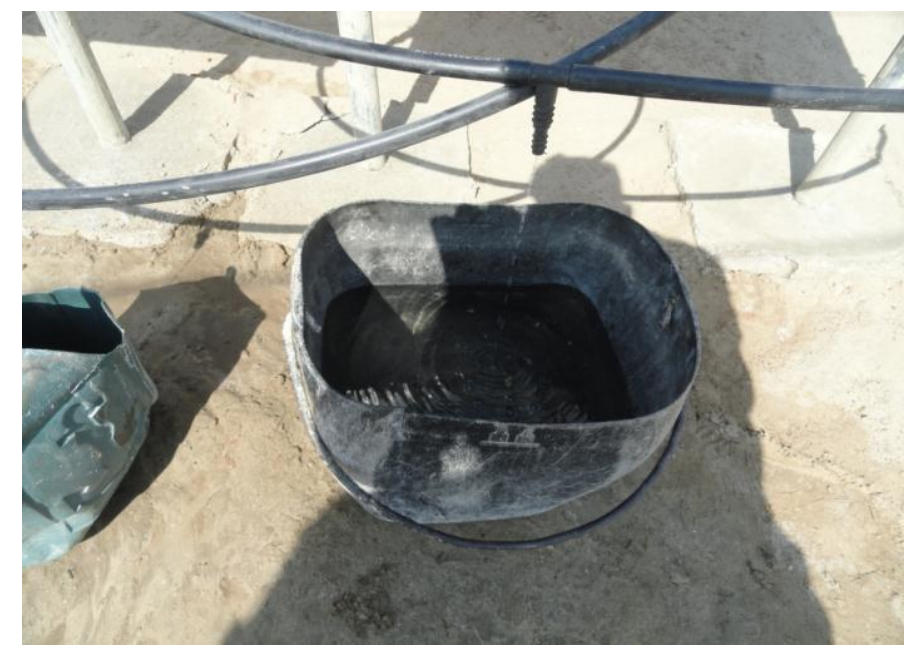

Working of Solar Desalination System in Field Areas of Umerkot

Under this study 08 solar desalination units were installed i.e. 2 solar desalination units at Goth Nawab Ji Dhani, Umer Kot, 2 solar desalination units at Goth Havalley Rehmatullah, Umer Kot and 4 solar desalination units at AZRI, Umerkot.

\section{Results And Discussions}

The purification of saline water into drinkable water depends upon the intake saline water capacity of each desalinization solar unit. During experimentation it was observed that intake water (saline water) should be adjusted @6 liters/hr/panel for the better working of the solar system. Data indicated in table- 
1 showed that 88 liters saline water provided the maximum drinkable water at the adjustment@6 liters/hr/panel at Arid Zone Research Institute, UmerKot. Solar units installed at GothNawab ji Dhani (Umerkot) also performed well to clean the saline water. Similar results were also determined at third location (Goth Haveli Rehmatullah, Umerkot). This table showed the better performance of the desalinization solar units if intake water adjustment was done @6 liters/hr/panel).Solar radiation removes a wide range of organic chemicals and pathogenic organisms by direct exposure, is relatively economical, and avoids cohort of harmful byproducts of chemically driven technologies (Calkins et al., 1976). More prominently, the economics of the process are approximately capacity self-reliant (Gloyna, 1971).The reduction in intensity varies with wavelength; for wavelengths ranging from 200 to $400 \mathrm{~nm}$ the reduction in intensity does not exceed $5 \% / \mathrm{m}$ of water depth; however, it rises as high as $40 \% / \mathrm{m}$ for longer wavelengths (Acra et al., 1990).Approximately $70 \%$ underground water is brackish/ saline. This water is unfit for drinking. The removal of excess salts from brackish water is the utmost requisite for the supply of drinkable water at the remote areas having dense saline water. Water quality is the main issues to save the whole humanity from epidemic diseases. Clean drinkable water is the basic right of the whole world. So this experiment was launched at three locations in District Umerkot represented areas of Thal/ desert in Sindh province of Pakistan. Electrical conductivity is the main criteria to evaluate the water fitness for drinking purpose. Data presented in table2 showed the performance of desalinization solar units installed. Brackish water having $14.45 \mathrm{dSm}^{-1}$ salts at Goth Nawab Ji Dhani (Umerkot) removed the toxic salts through solar desalinization technique and reduced it to $0.15 \mathrm{dSm}^{-1}$. Water having so minute salts is fit for drinking purpose. Similar results were also indicated from other two locations. Water analysis report issued by PCSWR shoed the fitness of the treated water through the utilization of this solar desalinization process at Umerkot sites. Utilization of sunlight for the reclamation of brackish water through solar desalinization is the friendly environment, most economical and easily installed with local training. Maintenance cost of these solar units is also very minute. The use of solar irradiation for treatment of chemically and biologically contaminated water is not a new trend (Calkins et al., 1976: Conroy et al., 1996; Davies-Colley et al., 1994; Malik et al., 1982; Safapour and Metcalf, 1999; Sinton et al., 1999, 2002).

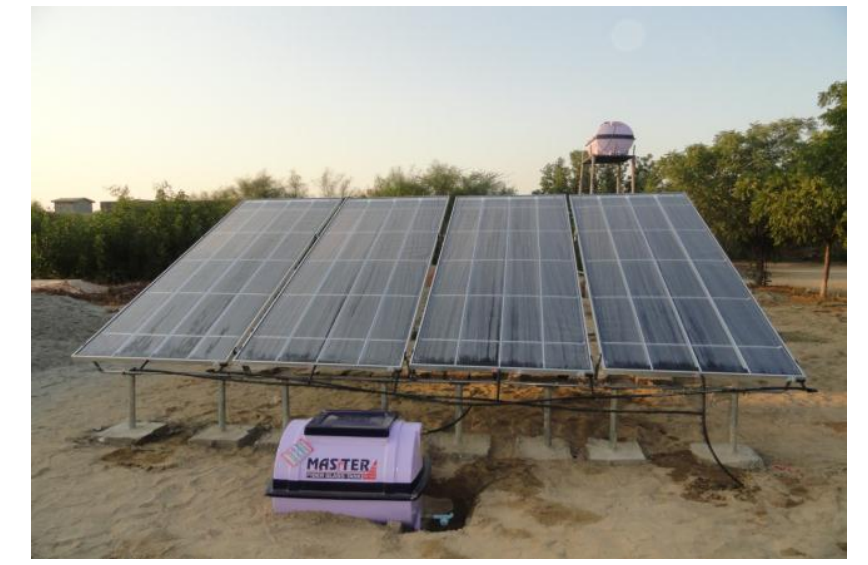

Four unit of solar desalination installed at AZRI, Umerkot, Sindh

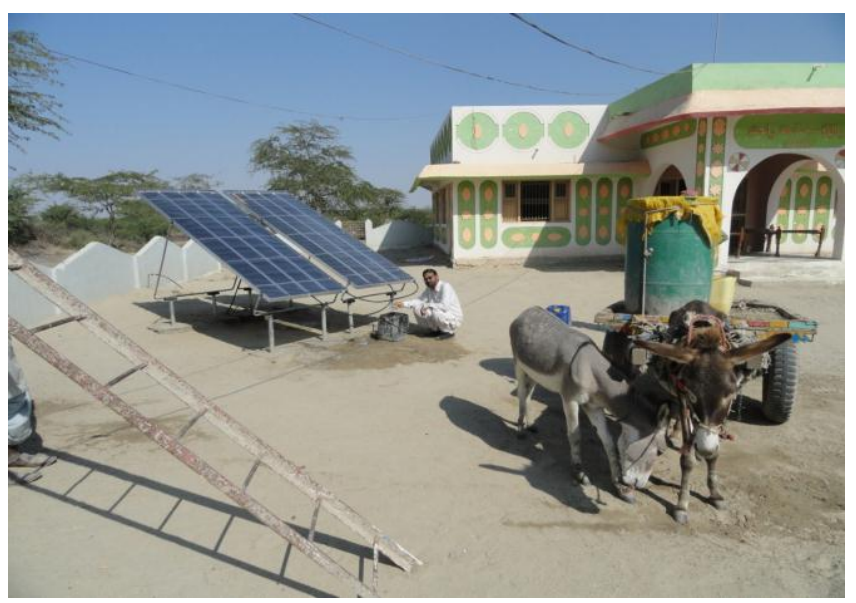

Two unit of solar desalination at Havelli Rahmatullah, Umerkot, Sindh 
Reclamation of Saline Water through Solar Desalinization Process under Arid/Semi-Arid of Thar at Umerkot District, Sindh, Pakistan

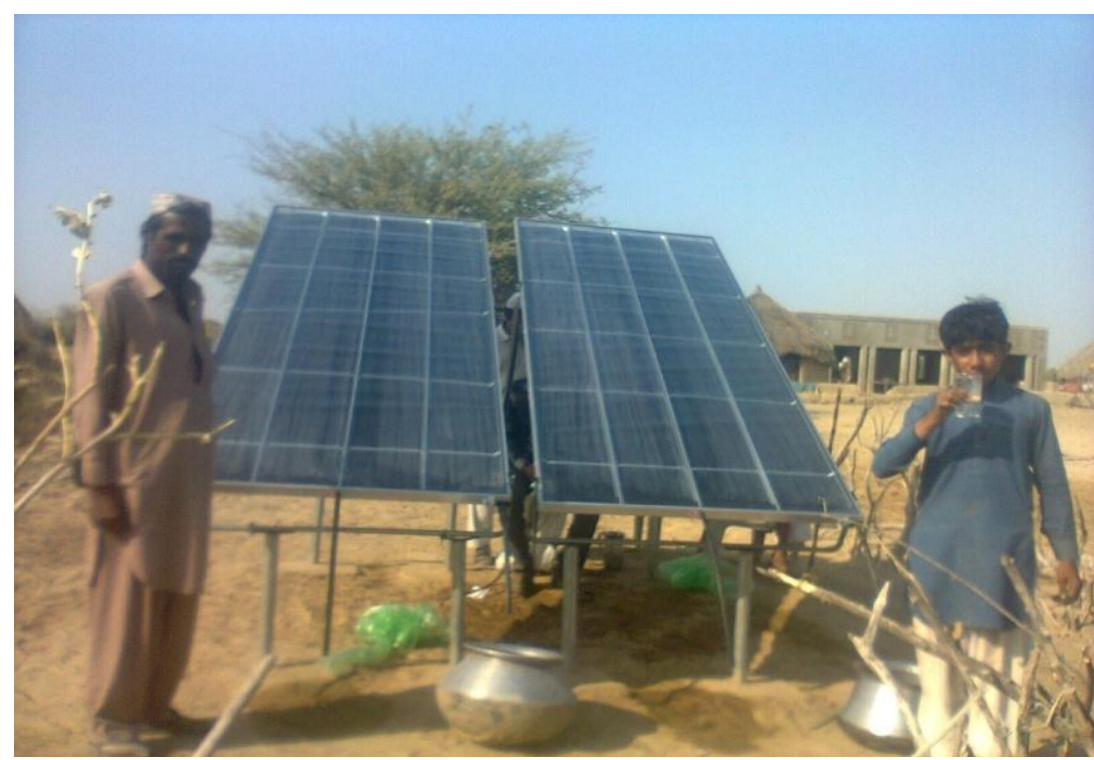

Two unit of solar desalination at Goth Nawab Ji Dhani, Umerkot, Sindh

\section{Water analys is report of Umerkot installed desalination units}

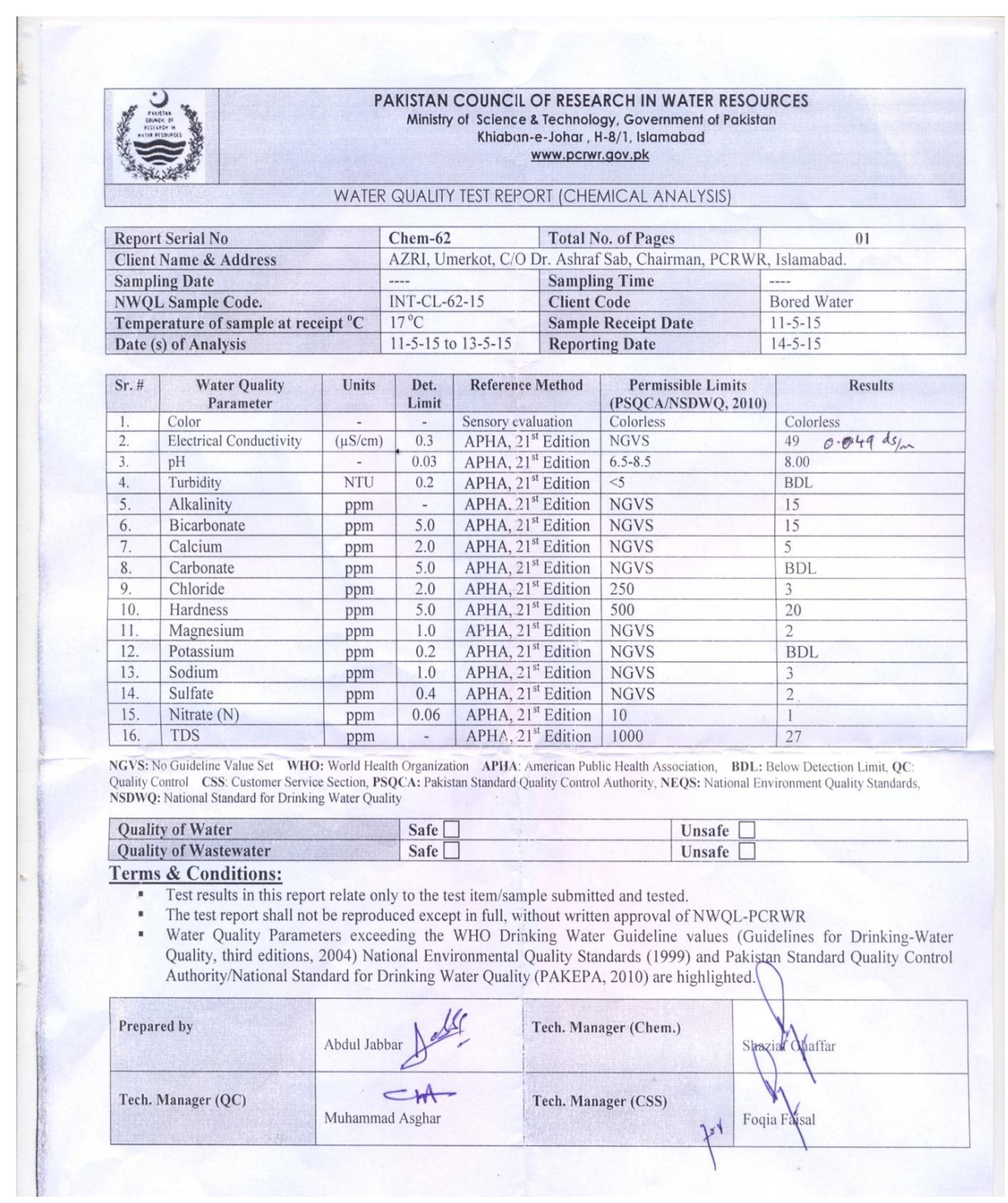


Reclamation of Saline Water through Solar Desalinization Process under Arid/Semi-Arid of Thar at Umerkot District, Sindh, Pakistan

\section{GOVERNMENT OF SINDH AGRICULTURE CHEMISTRY (S.F) SECTION AGRICULTURE RESEARCH INSTITUTE, TANDOJAM}

No. A.C (S.F) / Admn. / 225 of 2015

Dated the $07-01-2015$

Name of Grower: Lal Chand UmerKot

The Water samples were collected from the grower and same were analyzed in the

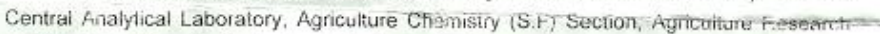
Institute Tandojam for their physical and chensicai progerties

WATER ANALYTICAL DATA

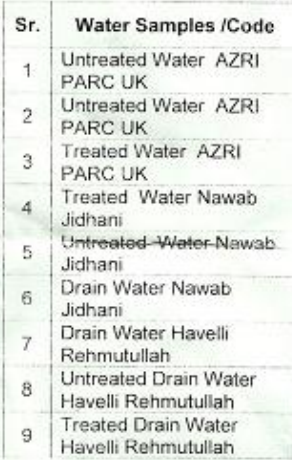

\begin{tabular}{|c|c|c|c|}
\hline $\begin{array}{c}\mathrm{EC} \\
\text { (dSim) }\end{array}$ & $\mathrm{pH}$ & $\begin{array}{c}\text { TSS } \\
\text { (ppm) }\end{array}$ & Remarks \\
\hline 327 & 8.2 & 2093 & Unff \\
\hline 4.22 & 8.3 & 2701 & Unfit \\
\hline 039 & 8.4 & 250 & $1^{\text {"I }}$ \\
\hline 0.15 & 8.0 & 96 & $1^{n}$ \\
\hline 12,45 & 87 & $101 i 5$ & Untit \\
\hline 1233 & 8.1 & 8631 & Unfit \\
\hline 16.22 & 7.8 & 13454 & Unfit \\
\hline 19.20 & 7.8 & 13440 & Unfit \\
\hline 0.77 & 7.7 & 493 & $3^{x}$ \\
\hline
\end{tabular}

Results: Water samples analysed in Soil anc Water resting Laboratory. according to results, Sr.\# 3,4,9 are come in first class category whereas $\mathrm{Sr}, \# 1,2,5,6,7$ and 8 are unfit for irrigation purpose

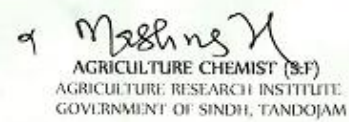

Table1. Performance Evaluation of 8 Desalinization units at Multiple locations of Umerkot District, Sindh, Pakistan

\begin{tabular}{|c|c|c|c|c|c|c|c|c|}
\hline \multicolumn{9}{|c|}{ Latitude $=25^{\circ} 21^{\prime} 41.2^{\prime \prime} \mathrm{N}$, Longitude $=69^{\circ} 44^{\prime} 36.91^{\prime \prime} \mathrm{E}$ or 25.361444 and 69.743586} \\
\hline Month & Temp & $\overline{\left.\mathrm{C}^{\circ}\right)}$ & Ave. Discl & $\operatorname{arge}\left(\mathrm{lh}^{-1}\right.$ & & Solar & Solar & Volume of treated \\
\hline January & Max. & Min. & Untreated & Treated & Drained & Nos & Umerkot & Liters \\
\hline Arid Zone & 25.4 & 18.5 & $88(24)$ & 7 & 80 & 4 & 200 & 56 \\
\hline Research & & & $80(24)$ & 5 & 72 & 4 & 200 & 40 \\
\hline Institute, & & & $72(24)$ & 4 & 60 & 4 & 200 & 32 \\
\hline Umerkot. & & & $64(24)$ & 6 & 58 & 4 & 200 & 48 \\
\hline $\begin{array}{l}\text { GothNawab } \\
\text { ji Dhani. }\end{array}$ & 25.4 & 18.5 & $36(12)$ & 3 & - & 2 & 200 & 24 \\
\hline $\begin{array}{l}\text { Goth Haveli } \\
\text { Rehmatullah. }\end{array}$ & 25.4 & 18.5 & $40(12)$ & 4.28 & 18 & 2 & 200 & 34 \\
\hline
\end{tabular}

The discharge of intake water (untreated) should be adjusted @6 liters/hr/panel

Table2. Drinking water Quality Evaluation of Desalinization units at Multiple locations of Umerkot District, Sindh, Pakistan (Latitude $=25^{\circ} 21^{\prime} 41.2^{\prime \prime} \mathrm{N}$, Longitude $=69^{\circ} 44^{\prime} 36.91^{\prime \prime} \mathrm{E}$ )

\begin{tabular}{|c|c|c|c|c|c|c|c|c|c|}
\hline \multirow{2}{*}{$\begin{array}{l}\text { Brackishwater } \\
\text { with source }\end{array}$} & \multicolumn{3}{|c|}{ Untreated Water } & \multicolumn{3}{|c|}{ Treated Water } & \multicolumn{3}{|c|}{ Drained Water } \\
\hline & $\begin{array}{l}\mathrm{ECW} \\
\left(\mathrm{dSm}^{-1}\right)\end{array}$ & TSS(ppm) & $\mathrm{pH}$ & $\begin{array}{l}\mathrm{ECW} \\
\left(\mathrm{dSm}^{-1}\right)\end{array}$ & $\begin{array}{l}\text { TSS } \\
(\mathrm{ppm})\end{array}$ & $\mathrm{pH}$ & $\begin{array}{l}\mathrm{ECw}(\mathrm{dSm}- \\
\text { 1) }\end{array}$ & $\begin{array}{l}\text { TSS } \\
(\mathrm{ppm})\end{array}$ & $\mathrm{pH}$ \\
\hline $\begin{array}{l}\text { Goth Nawab } \\
\text { Ji Dhani }\end{array}$ & 14.45 & 10,115 & 8.1 & 0.15 & 96 & 8.0 & 12.33 & 8631 & 8.1 \\
\hline $\begin{array}{l}\text { GothHaveli } \\
\text { Rehmatullah }\end{array}$ & 19.20 & 13,440 & 7.8 & 0.17 & 49 & 7.7 & 19.22 & 13,454 & 7.8 \\
\hline $\begin{array}{l}\text { AZRI, } \\
\text { UmerKot }\end{array}$ & 3.27 & 2093 & 8.2 & 0.39 & 250 & 8.4 & 4.22 & 2701 & 8.3 \\
\hline
\end{tabular}




\section{REFERENCES}

Acher, A., E. Fischer, R. Turnheim, and Y. Manor. 1997. Ecologically friendly wastewater disinfection techniques. Water Res. 31:1398-1404.

Acra, A., M. Jurdi, H. Mu'allem, Y. Karahagopian, and Z. Raffoul. 1990. Water disinfection by solar radiation. Assessment and application. IDRCTS66e. International Development Research Centre, Ottawa, Canada.

Bunce, N. J. 1991. Environmental chemistry, p. 183-214. Wuerz Publishing Ltd., Winnipeg, Canada.

Calkins, J., J. D. Buckles, and J. R. Moeller. 1976. The role of solar ultraviolet radiation in "natural" water purification. Photochem. Photobiol. 24: 49-57.

Conroy, R. M., M. Elmore-Meegan, T. Joyce, K. G. McGuigan, and J. Barnes. 1996. Solar disinfection of drinking water and diarrhoea in Maasai children: a controlled field trial. Lancet 348:1695-1697.

Davies-Colley, R. J., R. G. Bell, and A. M. Donnison. 1994. Sunlight inactivation of enterococci and fecal coliforms in sewage effluent diluted in seawater. Appl. Environ. Microbiol. 60:2049-2058.

Dev Rahul, and Tiwari G.N., 2009.Characteristic equation of a passive solar still Desalination, 19; 245-246.

Gloyna, E. F. 1971. Waste stabilization ponds. World Health Organization, Geneva, Switzerland.Greenlee L. F., D. F. Lawler, B. D. Freeman, B. Marrot, and P. Moulin, 2009. Reverse osmosis desalination: water sources, technology, and today's challenges. Water Research.43( 9): 2317-2348.

Ishikawa, T., T. Sato, Y. Ose, and H. Nagase. 1986. Reaction of chlorine and bromide with humic substance. Sci. Total Environ. 54:185-194.

Malik, M. A. S., G. N. Tiwari, A. Kumar, and M. S. Sodha. 1982. Solar distillation: a practical study of a wide range of stills and their optimum design, construction and performance. Pergamon Press, Oxford, United Kingdom.

Pelizzetti, E. 1999. Solar water detoxification. Current status and perspectives. Z. Phys. Chem. 212:207-218.

Safapour, N., and R. H. Metcalf. 1999. Enhancement of solar water pasteurization with reflectors. Appl. Environ. Microbiol. 65:859-861.

Sinton, L. W., C. H. Hall, P. A. Lynch, and R. J. Davies-Colley. 2002. Sunlight inactivation of fecal indicator bacteria and bacteriophages from waste stabilization pond effluent in fresh and saline waters. Appl. Environ. Microbiol. 68:1122-1131.

Sinton, L. W., R. K. Finlay, and P. A. Lynch. 1999. Sunlight inactivation of fecal bacteriophages and bacteria in sewage-polluted seawater. Appl. Environ. Microbiol. 65:3605-3613

U.S. Environmental Protection Agency. 1996. Ultraviolet light disinfection technology in drinking water application: an overview. EPA 811-R-96-002. U.S. Environmental Protection Agency, Washington, D.C.

Citation: M. Ullah et al., "Reclamation of Saline Water through Solar Desalinization Process under Arid/Semi Arid of Thar at Umerkot District, Sindh, Pakistan", International Journal of Advanced Research in Chemical Science (IJARCS), vol. 5, no. 5, pp. 1-7, 2018. http://dx.doi.org/10.20431/2349-0403.0505001

Copyright: (1) 2018 Authors. This is an open-access article distributed under the terms of the Creative Commons Attribution License, which permits unrestricted use, distribution, and reproduction in any medium, provided the original author and source are credited. 